\title{
Studies on Recently Isolated Cultures of Methicillin-resistant Staphylococcus aureus
}

\author{
By R. W. LACEY AND ANNE STOKES \\ Department of Bacteriology, North Cambridgeshire Hospital, \\ Wisbech, Cambridgeshire
}

(Received 20 November 1978)

\begin{abstract}
Of 19 recently isolated cultures of methicillin-resistant Staphylococcus aureus, 18 showed inducible low-level resistance to minocycline, 15 showed high-level resistance to streptomycin, and 4 showed resistance to low levels of streptomycin. Two cultures produced yellow pigment and may have been derived in vivo by loss of a gene(s) determining orange pigment.

Treatment of three cultures with serial exposures to $N$-methyl- $N^{\prime}$-nitro- $N$-nitrosoguanidine resulted in a widening of phage typing pattern that included all reactions in group $I$, the great majority in group III, but none in group II. The widening in phage lysis was possibly due to the elimination of defective prophages. Transfer of tetracycline resistance occurred from 12 out of the 19 cultures to a recipient in mixed culture; this transfer required either $\mathrm{Ca}^{2+}$ or $\mathrm{Mg}^{2+}$, was abolished by citrate, and enhanced by high cell density. It was probably mediated by defective bacteriophages.

No evidence was obtained for the occurrence of recombination within the methicillinresistant clone in nature. Eleven methicillin-resistant cultures stored for at least 5 years on agar slopes at $20^{\circ} \mathrm{C}$ had all lost this resistance at high frequency.
\end{abstract}

\section{INTRODUCTION}

During the last 25 years, epidemics of sepsis in hospitals have been caused by strains of Staphylococcus aureus varying in many properties, notably antibiotic sensitivity, bacteriophage typing pattern, production of pigment, carriage of prophages and extracellular products.

Epidemic strains within a particular phage group may harbour new prophages; the effect of this carriage is to narrow, or occasionally to widen, the range of lysis by typing phages. There is considerable evidence for the occurrence of lysogenization in nature within phage group I (Asheshov \& Rippon, 1959; Rountree, 1959; Rountree \& Asheshov, 1961; Asheshov \& Winkler, 1966) and phage group III (Jevons \& Parker, 1964; Jevons et al., 1966; Rosendal \& Bülow, 1971; Parker et al., 1974).

Phage group II strains are distinct both epidemiologically and genetically from the other major phage groups; this is illustrated in the possession by group II strains of restriction endonucleases that give them immunity to the typing phages of groups I and III. These enzymes can be inactivated by heating; hence the spectrum of lysis of phage group II staphylococci by typing phages increases after heating (Asheshov \& Jevons, 1963; Ralston \& Baer, 1964; Stobberingh \& Winkler, 1976). A further type of phage 'immunity' is the failure of typing phage 187 to adsorb to the great majority of staphylococcal strains (Odeing, 1974). Thus, although there is good evidence for the occurrence of a number of recent evolutionary events within phage groups I or III in nature, it is not clear whether there is close affinity between these groups. 'Methicillin-resistant' staphylococci, whilst frequently giving 
reactions in group III, may also be lysed by phages 29 or 79 in group I (Parker et al., 1974). The study of these cultures should give some insight into the relationships between phage groups I and III; such study of methicillin-resistant cultures is facilitated by their possession of some stable properties that permit identification of derivatives independently from phage typing reactions. This paper describes these experiments.

\section{METHODS}

Methicillin-resistant staphylococci. Strains M1 to M19 were isolated from laboratories in the U.K. between 1976 and 1978 (Table 1). Thrice-purified clones were stored without subculture on nutrient agar slopes at $20{ }^{\circ} \mathrm{C}$. Before use, each slope was subcultured to a 'master' plate stored at $4{ }^{\circ} \mathrm{C}$ before further subculture. In addition, 11 methicillin-resistant cultures described previously $(13136,13137,9254,2273,9463,11164$, B109, 8657, FAR1, FAR2, B262; Lacey \& Grinsted, 1973) were used.

Strains 6936 and 609 were also used (Lacey, 1971). A rifampicin-resistant (minimum inhibitory concentration $>100 \mu \mathrm{g} \mathrm{ml}^{-1}$ ) mutant of strain 6936 was used as recipient in transfer experiments.

Media. Nutrient broth was Oxoid no. 2 and nutrient agar was mast blood agar base (DM100). Pigmentation was recorded after incubation of individual colonies on milk agar (Lacey, 1971).

Mutagenesis with $N$-methyl- $N^{\prime}$-nitro- $N$-nitrosoguanidine (nitrosoguanidine). Static overnight cultures containing about $5 \times 10^{8}$ viable cocci ml-1 were added to a freshly prepared solution of nitrosoguanidine (from Sigma) in distilled water at a final concentration of $100 \mu \mathrm{g} \mathrm{ml}^{-1}$. The mixture was held at $37^{\circ} \mathrm{C}$ statically for between 10 and $60 \mathrm{~min}$, then diluted in physiological saline and spread over the surface of milk agar plates. After incubation for $24 \mathrm{~h}$ at $37^{\circ} \mathrm{C}$, followed by $24 \mathrm{~h}$ incubation at room temperature, colonies were subcultured from plates containing about $1 \%$ surviving cocci. Such colonies appeared pleomorphic in pigment and size, many minute colonies being evident. Colonies comparable in size to those of the wild strain were selected at random and subcultured to milk agar. They were then tested for antibiotic sensitivity, including the possession of heterogeneous resistance to methicillin and high-level resistance to streptomycin. They were subsequently phage typed and then some were re-checked for antibiotic sensitivity. Some were stored on agar slopes and checked for stability of phage reactions on two subsequent occasions.

Mitomycin C and ultraviolet induction. These were attempted by the method of Lacey (1971). Mitomycin $\mathrm{C}$ (from Sigma) was added at concentrations of $0 \cdot 1,0 \cdot 5,2 \cdot 5,5 \cdot 0$ and $20.0 \mu \mathrm{g} \mathrm{ml}^{-1}$. A culture (strain 609) known to undergo induction with either mitomycin $\mathrm{C}$ or ultraviolet light was included in each set of experiments. Cultures were incubated for 4 to $6 \mathrm{~h}$ at $37^{\circ} \mathrm{C}$ following exposure to mitomycin $\mathrm{C}$ or ultraviolet irradiation and then examined for lysis. If no lytic activity was observed, cultures were held at room temperature for up to $48 \mathrm{~h}$ and examined for subsequent lysis.

Transduction and phage propagation. The method of Lacey (1971) was used. Possible transductants were selected on media containing either $0 \cdot 1 \mathrm{mM}^{-\mathrm{CdCl}_{2}}, 2 \cdot 5 \mu \mathrm{g}$ tetracycline $\mathrm{ml}^{-1}$ or $5 \mu \mathrm{g}$ erythromycin $\mathrm{ml}^{-1}$. For the latter, $0.5 \mu \mathrm{g}$ erythromycin $\mathrm{ml}^{-1}$ was added with the sodium citrate in order to ensure induction of erythromycin resistance. Irradiation with ultraviolet light was as previously described (Lacey, 1971).

Transfer of antibiotic resistance between staphylococci in mixed cultures. This was done by the method of Lacey (1971) except that the counterselecting agent was $10 \mu \mathrm{g}$ rifampicin $\mathrm{ml}^{-1}$ and either $0.1 \mathrm{mM}-\mathrm{CdCl}_{2}$, $2.5 \mu \mathrm{g}$ erythromycin $\mathrm{ml}^{-1}, 2.5 \mu \mathrm{g}$ tetracycline $\mathrm{ml}^{-1}, 25 \mu \mathrm{g}$ methicillin $\mathrm{ml}^{-1}, 10 \mu \mathrm{g}$ streptomycin $\mathrm{ml}^{-1}, 2.5 \mu \mathrm{g}$ neomycin $\mathrm{ml}^{-1}$ or $2.5 \mu \mathrm{g}$ gentamicin $\mathrm{ml}^{-1}$ incorporated into nutrient agar.

Attempt at transfer of pigment between strains. Potential donor and recipient cultures were inoculated into nutrient broth containing $10 \mathrm{mM}-\mathrm{CaCl}_{2}$ or human blood to a final density of $10^{5}$ colony-forming units (c.f.u.) $\mathrm{ml}^{-1}$ of each. After $24 \mathrm{~h}$ incubation at $37^{\circ} \mathrm{C}$ with agitation, the mixtures were diluted and applied to the surface of milk agar plates containing an agent to suppress the growth of the donor. These were incubated for $2 \mathrm{~d}$ at $37^{\circ} \mathrm{C}$. It was possible to detect an altered pigment type from an inoculum of about $10^{3}$ c.f.u. per plate.

Loss of methicillin resistance from stored cultures. Agar slopes of 11 strains previously described (Lacey \& Grinsted, 1973) had been stored without subculture in the dark at room temperature for between 5 and 6 years. Nutrient broth $(0 \cdot 1 \mathrm{ml})$ was added to each slope and then pipetted into $10 \mathrm{ml}$ nutrient broth and incubated statically overnight at $37^{\circ} \mathrm{C}$. Master plates containing $5 \mu \mathrm{g}$ tetracycline $\mathrm{ml}^{-1}$ were prepared from dilutions of these cultures and subsequently replica-plated to nutrient agar plates containing 10 or $25 \mu \mathrm{g}$ methicillin $\mathrm{ml}^{-1}$. After $20 \mathrm{~h}$ incubation at $30^{\circ} \mathrm{C}$, six of the resultant methicillin-sensitive variants from each strain were subcultured and examined for general properties including phage typing. (The use of tetracycline in the master plates was a precaution against possible contamination occurring during prolonged storage.)

Bacteriophage typing. This was performed by a conventional procedure at routine test dilution with typing phages $29,52,52 \mathrm{~A}, 79,80,3 \mathrm{~A}, 3 \mathrm{C}, 55,71,95,6,42 \mathrm{E}, 47,53,54,75,77,83 \mathrm{~A}, 84,85,81,94,96$ and 88. 
Table 1. Source of methicillin-resistant staphylococci

$\begin{array}{clcc}\text { Strain no. } & \text { Source } & \text { Date } & \begin{array}{c}\text { Phage } \\ \text { pattern* }\end{array} \\ \text { M1 } & \text { Wisbech } & 1978 & 77 \\ \text { M2 } & \text { Fife } & 1976 & 77 \\ \text { M3 } & \text { Fife } & 1976 & 77 \\ \text { M4 } & \text { Fife } & 1976 & 79 / 77 \\ \text { M5 } & \text { Fife } & 1976 & 77 \\ \text { M6 } & \text { King's Lynn } & 1976 & 79 / 77 \\ \text { M7 } & \text { King's Lynn } & 1976 & 77 \\ \text { M8 } & \text { King's Lynn } & 1978 & 79 / 77 \\ \text { M9 } & \text { Mansfield } & 1977 & 77 \\ \text { M10 } & \text { Mansfield } & 1977 & 77 \\ \text { M11 } & \text { Mansfield } & 1977 & 77 / 84 \\ \text { M12 } & \text { Fife } & 1976 & 79 / 77 \\ \text { M13 } & \text { Cambridge } & 1977 & 77 \\ \text { M14 } & \text { Cambridge } & 1977 & 77 \\ \text { M15 } & \text { Cambridge } & 1977 & \text { NT } \dagger \\ \text { M16 } & \text { Cambridge } & 1977 & 88 \\ \text { M17 } & \text { Cambridge } & 1977 & 88 \\ \text { M18 } & \text { Cambridge } & 1977 & 88 \\ \text { M19 } & \text { King's Lynn } & 1978 & 79 / 77 \\ * & \text { At routine test dilutions. } & \dagger \text { NT, Non-typable. }\end{array}$

The medium (defined phage agar) contained Oxoid nutrient broth no. $2\left(20 \mathrm{~g} \mathrm{l}^{-1}\right), \mathrm{NaCl}\left(5 \mathrm{~g} \mathrm{l}^{-1}\right)$ and $\mathrm{Lab} \mathrm{M}$ $\operatorname{agar}\left(7 \cdot 5 \mathrm{~g} \mathrm{l}^{-1}\right)$. After autoclaving, $\mathrm{CaCl}_{2} \cdot 2 \mathrm{H}_{2} \mathrm{O}\left(1 \cdot 47 \mathrm{~g} \mathrm{l}^{-1}\right)$ was added. Lytic reactions refer to major reactions $(++,>50$ plaques). Cross-spotting for the detection of phage particles in culture filtrates was performed by applying filtered $\left(0.45 \mu \mathrm{m}\right.$ pore size, Millipore) centrifuged cultures grown at $37^{\circ} \mathrm{C}$ in nutrient broth to phage agar plates seeded with a prospective indicator culture as for phage typing.

Determination of antibiotic sensitivity. Preliminary disc results were confirmed by the estimation of minimal inhibitory concentrations (m.i.c.). Cultures examined for methicillin resistance were subcultured on antibiotic-free agar and inoculated into nutrient broth that was incubated overnight at $37^{\circ} \mathrm{C}$. Then undiluted cultures and cultures diluted in nutrient broth to $10^{-2}, 10^{-4}$ and $10^{-6}$ were applied to the surface of plates (giving $10^{1}$ to $10^{7}$ c.f.u. per inoculum) containing a range of concentrations of methicillin or cloxacillin. These plates were incubated at $30^{\circ} \mathrm{C}$ or $37^{\circ} \mathrm{C}$ for $48 \mathrm{~h}$. Cultures described here as methicillin-resistant exhibited the following characteristics: (i) a greater intrinsic resistance to methicillin than cloxacillin at $30{ }^{\circ} \mathrm{C}$ and $37^{\circ} \mathrm{C}$ with each inoculum; (ii) a greater resistance to both antibiotics at $30^{\circ} \mathrm{C}$ than at $37^{\circ} \mathrm{C}$ for a given inoculum and time of incubation; (iii) a very marked inoculum effect for either antibiotic at $37^{\circ} \mathrm{C}$ with very few cocci (about $10^{-5}$ ) growing on $100 \mu \mathrm{g}$ methicillin ml-1 after 24 or $48 \mathrm{~h}$, but little such effect at $30^{\circ} \mathrm{C}$; (iv) any colonies surviving high levels of antibiotic at $37^{\circ} \mathrm{C}$ being slow-growing and pleomorphic.

Inducible antibiotic resistance. To test for inducibility of resistance to erythromycin, minocycline, streptomycin and gentamicin, cultures were incubated in the presence of $0.5 \mu \mathrm{g} \mathrm{ml}^{-1}$ of each antibiotic for $18 \mathrm{~h}$, before determinations of m.i.c. Dilutions closer than doubling were used to test for inducibility.

\section{RESULTS AND DISCUSSION}

\section{General properties of recent methicillin-resistant isolates}

All 19 isolates showed characteristic heterogeneous resistance to methicillin; they were also resistant to tetracycline and to a variety of other antibiotics (Table 2). Although 15 isolates showed the non-inducible high-level resistance to streptomycin (m.i.c. $>10 \mathrm{mg}$ $\mathrm{ml}^{-1}$ ) that is characteristic of these cultures (Lacey \& Grinsted, 1973), four isolates (M15, M16, M17 and M18) showed non-inducible low-level resistance to streptomycin (m.i.c. $40 \mu \mathrm{g} \mathrm{ml}^{-1}$ ). All except one (M12) showed inducible low-level resistance to minocycline with m.i.c. values varying from 3 to $10 \mu \mathrm{g} \mathrm{ml}^{-1}$ when uninduced to 5 to $25 \mu \mathrm{g} \mathrm{ml}^{-1}$ after preincubation with $0.5 \mu \mathrm{g}$ minocycline $\mathrm{ml}^{-1}$. This resistance appears identical to that described by Asheshov (1975). The 11 cultures described previously (Lacey \& Grinsted, 1973) were also examined for minocycline resistance; all except three showed low-level 


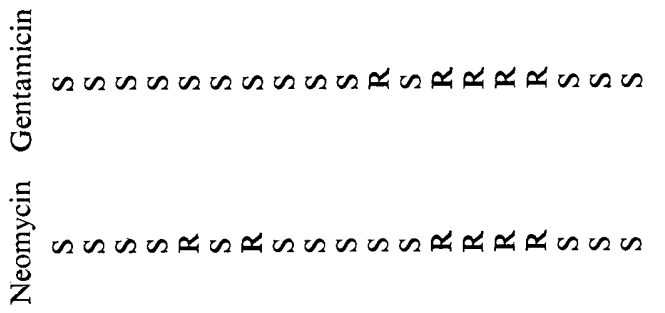

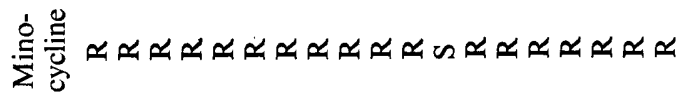

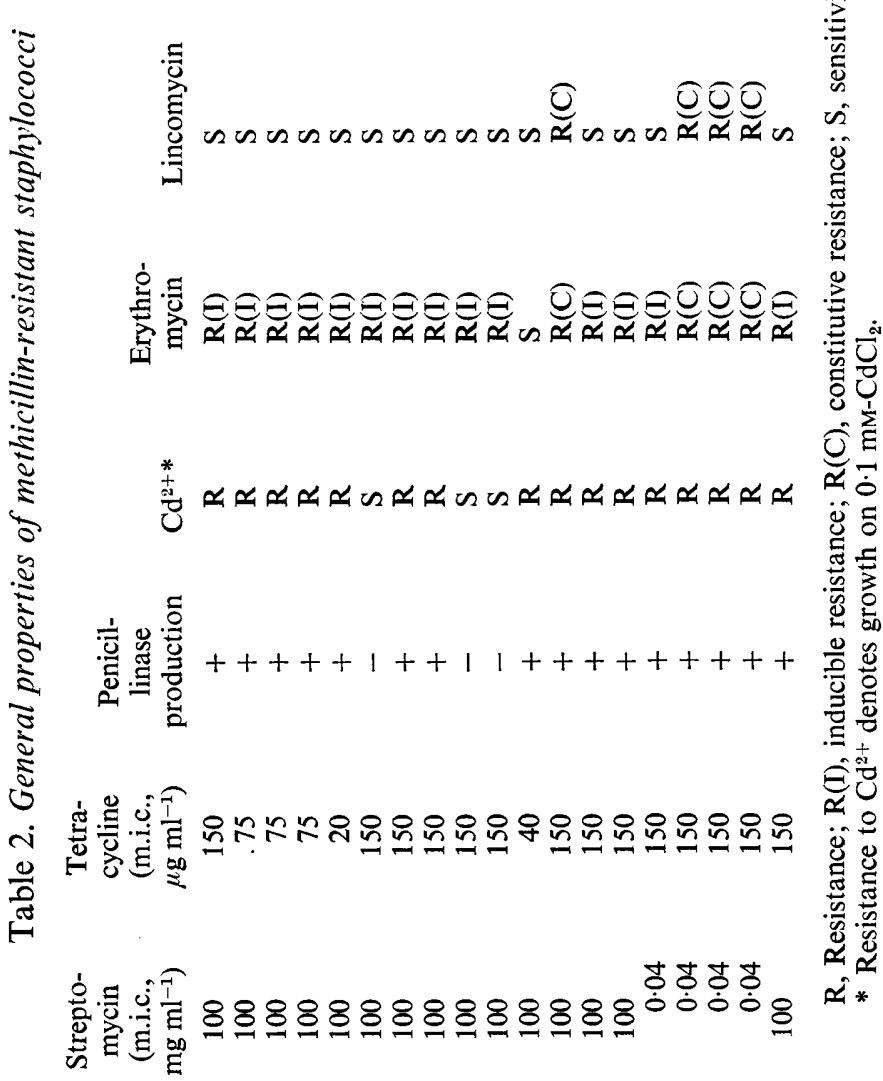

离 
Table 3. Widening of phage typing pattern (routine test dilution) following four successive treatments of M2 and M17 with nitrosoguanidine

$\begin{array}{lll}\text { Wild strain (typing pattern) } & \text { M2 (77) } & \text { M17 (88) } \\ \text { No. of derivatives examined } & 483 & 370 \\ \text { Phage patterns of mutants } & 54 / 77 & 88 / 80 / 83 \mathrm{~A} / 85 \\ & 79 / 77 & \text { Non-typable } \\ & 29 / 54 / 77 & 88 / 29 / 52 / 52 \mathrm{~A} / 80 / 95 / 42 \mathrm{E} / 83 \mathrm{~A} \\ & 29 / 79 / 54 / 77 & 88 / 80 \\ & 29 / 79 / 54 / 75 / 77 / 85 & 88 / 29 / 52 / 52 \mathrm{~A} / 80 / 95 / 83 \mathrm{~A} \\ 47 / 54 / 77 & 88 / 52 / 52 \mathrm{~A} / 80 \\ 29 / 79 / 6 / 42 \mathrm{E} / 47 / 54 / 75 / 77 / 85 / 81 & 88 / 83 \mathrm{~A} \\ 47 / 54 / 77 / 81 & 88 / 52 / 80 \\ 29 / 79 / 47 / 54 / 77 & 88 / 52 / 52 \mathrm{~A} / 80 / 95 \\ & 79 / 54 / 77 & 88 / 29 / 80 \\ & 29 / 42 \mathrm{E} / 47 / 54 & 88 / 52 / 52 \mathrm{~A} / 80 / 83 \mathrm{~A} \\ & 79 / 47 / 54 & 88 / 80 / 54 \\ 47 / 54 & 80 \\ & 47 / 54 / 77 / 85 & 88 / 85 \\ 29 / 47 / 54 & 88 / 52 \mathrm{~A} / 80 / 83 \mathrm{~A} \\ & 29 / 77 & \\ 54 & \\ 29 / 79 / 77 & \\ 29 / 79 / 42 \mathrm{E} / 47 / 54 / 75 / 77 / 85 & \\ 47 / 54 / 75 / 77 / 85 / 81 & \\ \text { Non-typable } & \end{array}$

inducible resistance to minocycline. Thus, from a total of 30 methicillin-resistant cultures isolated between 1960 and 1978, 26 showed inducible low-level resistance to minocycline.

Seventeen cultures produced orange pigment on milk agar and two (M9 and M10) produced yellow pigment.

\section{Alterations in bacteriophage typing patterns of three methicillin-resistant cultures following nitrosoguanidine treatment}

Strains M2, M14 and M17 are typical recent methicillin-resistant isolates (see Tables 1 and 2). Phage typing of these isolates on different occasions showed that their typing reactions were stable. On one occasion, 50 different colonies from four independent platings of strain M17 were typed and all gave a major reaction to phage 88 and no other reaction. It was inferred, therefore, that there was little spontaneous variation in these patterns, so that the variation following treatment with nitrosoguanidine was a result of such treatment. Derivatives obtained after successive treatments of strain M2 are shown in Table 3. The following changes were seen: (i) a widening of reactions in groups I and III, the only reactions not detected being to phages $83 \mathrm{~A}$ and 84 , but no reactions to group II phages; (ii) loss of some reactions, so that some clones gave reactions exclusive to group I or III or were nontypable. Resistance to methicillin, streptomycin and tetracycline was retained by all the derivatives. Several of the clones having patterns widely different from the wild strain were typed in replicate on subsequent occasions and showed little alteration in typing pattern. Futher treatment of derivatives of strain M2 with nitrosoguanidine gave similar patterns, but after five successive treatments, the resultant organisms grew poorly, most being nontypable.

Mutagenesis of strain M17 also increased its phage susceptibility, with nine new major lytic reactions (Table 3). Mutagenesis of strain M14 (typing pattern 77) gave widening reactions in group III, so that clones typing $47 / 54 / 77 / 81$ and $6 / 42 \mathrm{E} / 47 / 54 / 75 / 77 / 81$ were found but no group I reactions were seen (results not shown). 


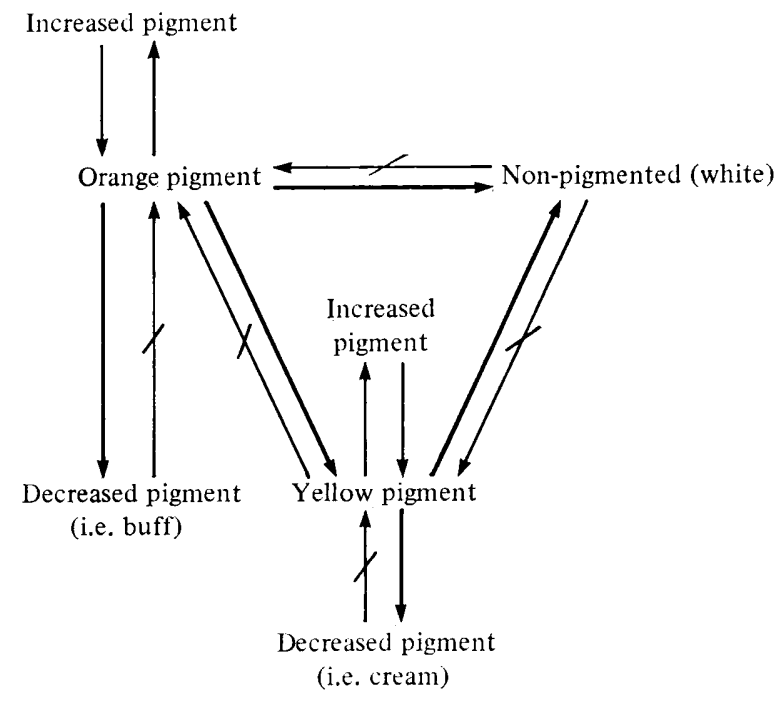

Fig. 1. Pathways of alteration of pigment in Staphylococcus aureus following treatment with nitrosoguanidine.

\section{Mutagenesis of pigmentation in M2, M9, M10 and M17}

Two cultures producing orange pigment (M2 and M17) were treated with nitrosoguanidine and yielded about $2 \%$ colonies that gave yellow pigment and $4 \%$ that were non-pigmented (white). Further treatment of these yellow-pigmented or white-pigmented cultures with nitrosoguanidine did not result in any orange colonies from about 10000 colonies screened. The yellow variants, however, yielded white colonies at the same frequency as above, but treatment of white colonies produced no further variants.

Treatment of the two yellow-pigmented cultures (M9 and M10) gave no orange colonies, and about $5 \%$ were non-pigmented. Further mutagenesis of the latter with nitrosoguanidine did not reverse this.

During these experiments, it was noted that variants were common (about $20 \%$ of total colonies) with pigmentation either more or less intense than the wild strains. Subculture of the more intensely coloured colonies caused this additional pigmentation to be lost, but the pigment in the less intensely pigmented colonies appeared stable. These events are summarized in Fig. 1.

Since, in general, most strains of Staphylococcus aureus, including methicillin-resistant cultures, produce orange pigment rather than either yellow or white, and the change from orange to yellow appears irreversible, it is likely that the capacity to produce orange pigment gives the cell a selective advantage over other pigment phenotypes. Indeed, in mixed cultures comprising one each of all three pigment types derived from $\mathrm{M} 2$, clones producing orange pigment overgrew the other types both in nutrient broth and in blood, and also survived better on glass (results not shown). However, because it has not been possible to construct strains isogenic apart from variation in pigment production, it is not possible to ascribe such survival differences to pigmentation per se. As before (Grinsted \& Lacey, 1973), in mixed culture experiments, we were unable to transfer the capacity to synthesize orange or yellow pigment to non-pigmented cultures.

Thus, the yellow-pigmented cultures M9 and M10 have features characteristic of other methicillin-resistant staphylococci and are probably derived from the predominant orange cultures. Yellow-pigmented methicillin-sensitive strains (e.g. Willis et al., 1966) might be derived similarly. 


\section{Table 4. Incidence of methicillin-sensitive bacteria in methicillin-resistant staphylococci stored for 5 to 6 years on agar slopes}

$\begin{array}{ccc}\text { Strain no. } & \begin{array}{c}\text { No. of } \\ \text { colonies } \\ \text { tested }\end{array} & \begin{array}{c}\text { No. (\%) } \\ \text { methicillin- } \\ \text { sensitive }\end{array} \\ 13136 & 286 & 6(2) \\ 13137 & 495 & 40(8) \\ 9254 & 846 & 64(7) \\ 2273 & 221 & 13(6) \\ 9463 & 68 & 7(10) \\ 11164 & 168 & 22(13) \\ \text { B109 } & 343 & 24(7) \\ 8657 & 506 & 10(2) \\ \text { FAR1 } & 488 & 215(43) \\ \text { FAR2 } & 191 & 7(4) \\ \text { B262 } & 168 & 8(5)\end{array}$

\section{Loss of methicillin resistance from stored cultures}

Although there is still uncertainty as to the precise cellular location of the genes determining methicillin resistance, the genetic features of this resistance are fairly uniform, although there have been conflicting reports over the stability of the resistance. Annear \& Grubb (1976) have reported reliable loss of the resistance in ageing broth cultures, although others consider the resistance to be stable.

Accordingly, 11 methicillin-resistant cultures (see Lacey \& Grinsted, 1973) stored for between 5 and 6 years on agar slopes without subculture were examined for the loss of the resistance by replica-plating. A recently isolated strain (M17) was also studied and from about 5000 colonies examined none sensitive to methicillin was detected. However, each of the methicillin-resistant cultures stored for at least 5 years yielded methicillin-sensitive derivatives (Table 4).

Six methicillin-sensitive variants (together with resistant cells) of each culture were examined for general sensitivity to antibiotics and were phage typed. No major changes in typing patterns were seen, and the only associated loss of resistance was that in three cultures a minority of the methicillin-sensitive cells were penicillinase-negative and sensitive to $\mathrm{Cd}^{2+}$ - presumably due to the coincidental loss of the penicillinase plasmid. Thus, these findings support those of Annear \& Grubb (1976), that instability of methicillin resistance on storage seems to be a general property of these strains.

\section{Evidence for recombination/transposons in methicillin-resistant cultures}

The properties of these methicillin-resistant cultures are in many ways similar to those previously described (Lacey, 1972; Lacey \& Grinsted, 1973). The cultures isolated recently are probably derived from these earlier strains. Thus, any changes detected in the recently isolated strains may be interpreted as being due to natural events within this cell line.

Transductants were obtained from the lysates of strains M9 and M11 after mitomycin C induction, and from strain M2 after propagation of typing phage 80 on a mutant clone lysed by this phage. From each of these lysates, transductants were obtained which were resistant to either tetracycline or $\mathrm{Cd}^{2+}$ (the latter were also penicillinase producers). Replica-plating of these colonies on to media containing single antibiotics to which these strains were also resistant (Table 2) showed that there was no cotransduction, i.e. the genomes (presumably plasmids in view of the frequencies obtained) determining penicillinase production and tetracycline resistance are still discrete, as was the case in the 'prototype' methicillinresistant isolate 13136 (Lacey \& Grinsted, 1973). Erythromycin was transduced at high frequency $\left(2.5 \times 10^{-6}\right)$ from the lysate of M2 by modified phage 80 to the recipient strain 6936. Ultraviolet treatment of the lysate showed an exponential decline in frequency, 
consistent with a plasmid locus for this resistance. There was no cotransduction of the other resistances, an unexpected finding since plasmid-mediated erythromycin resistance is usually linked to other resistances (see Lacey, 1975).

Each of the recipient colonies that acquired resistance to the antibiotics after mixed culture incubation (see below, Table 5) was replica-plated to media containing other relevant antibiotics added singly. Apart from one colony resistant to both minocycline and and tetracycline (presumably there had been coincidental rather than linked transfer), the only instance of linked transfer was the finding in strain M7 of a transmissible element determining resistance to neomycin, streptomycin and $\mathrm{Cd}^{2+}$ and also production of penicillinase. Approximately $90 \%$ of recipient cocci harbouring the transferred element showed the complete set of resistance traits. The level of resistance to streptomycin in the recipient harbouring these genes was low (m.i.c. $100 \mu \mathrm{g} \mathrm{ml}^{-1}$ ). This suggests that strain $\mathrm{M} 7$ is diploid for streptomycin resistance, one gene determining high-level resistance (m.i.c. $100 \mathrm{mg} \mathrm{ml}^{-1}$, Table 2), presumably chromosomal, and the other low-level resistance, presumably part of a polyfunctional plasmid.

\section{Explanation for the widening of typing pattern after mutagenesis}

The widening of the phage typing reaction following mutagenesis is likely to be due to the loss of one of the general mechanisms that protect the staphylococcal cell from bacteriophage lysis, i.e. (a) lysogenic immunity, $(b)$ failure of phage adsorption and $(c)$ restriction endonucleases. Each of these possibilities was investigated.

If the widening of phage typing was due to the loss of an entire temperate phage, then filtrates from the wild strains M2, M14 and M17 should contain particles lytic for the derivatives. Using a cross-spotting technique, filtrates from the wild strains were tested against 35 derivatives with a markedly widened phage typing reaction. No plaques were seen. Filtrates of cultures M2, M14 and M17 were also examined for the presence of plaqueforming activity on each of the propagating strains of the typing phages (see Methods) and on strains 609. 6936 and 1030 (strain 1030 is non-lysogenic and lysed by all the typing phages). No plaques were seen. These results suggest that M2, M14 and M17 do not harbour temperate phages, and that the widening in phage susceptibility is not associated with entire prophage loss.

If the cultures were 'normally' lysogenic, then they might be inducible with mitomycin C or ultraviolet light. Accordingly, each of the cultures M1 to M19 was treated with mitomycin $\mathrm{C}$ at concentrations from $0 \cdot 1$ to $20 \mu \mathrm{g} \mathrm{ml}^{-1}$ on three occasions; only two (M9 and M11) cleared. Cultures M2, M14 and M17 were also treated with varying doses of ultraviolet light. As with mitomycin $C$ treatment, a known lysogenic culture (strain 609) lysed, whereas none of these cultures did so. Filtrates of these cultures treated with either ultraviolet light or mitomycin $\mathbf{C}$ did not produce any plaques on the above cultures.

The second possibility $(b)$, that the wild strains could not adsorb typing phage particles whereas the mutants could, is unlikely because, phage 187 apart, all staphylococcal cultures adsorb typing phages whether or not they are subsequently lysed (Oeding, 1974). However, each wild strain and mutant which was lysed by typing phages 80,81 or $83 \mathrm{~A}$ was incubated for $30 \mathrm{~min}$ at $37^{\circ} \mathrm{C}$ with each of these phages, and then filtered. Both wild strains and the corresponding mutants adsorbed each phage similarly. Thus, widening of phage lysis is not explicable by enhanced phage adsorption.

The third possibility $(c)$, that treatment with nitrosoguanidine eliminated some of the genes determining restriction endonucleases, was examined as follows. If the wild strain did possess such enzymes, then it might be possible to inactivate them by heating the culture before application of phages (Stobberingh \& Winkler, 1976). Small volumes $(2.0 \mathrm{ml})$ were therefore incubated in a $56^{\circ} \mathrm{C}$ water bath for $0,1.5,2$ and 2.5 min before phage typing in the usual way, except that after application of phage, a duplicate set of plates was incubated at $37^{\circ} \mathrm{C}$. No widening of bacteriophage typing pattern was seen. Thus, no evidence for the 
Table 5. Transfer of resistances from strains M1 to M19 to recipient culture 6936

Results are expressed as the number of resistant recipients $\mathrm{ml}^{-1}$ after incubation of the mixed culture for $24 \mathrm{~h}$.

\begin{tabular}{|c|c|c|c|c|}
\hline Donor strain & $\begin{array}{l}\text { Tetracycline } \\
\text { resistance }\end{array}$ & $\begin{array}{c}\mathrm{Cd}^{2+} \text { resistance } \\
\text { and } \\
\text { penicillinase } \\
\text { production }\end{array}$ & $\begin{array}{l}\text { Erythromycin } \\
\text { resistance }\end{array}$ & $\begin{array}{l}\text { Neomycin } \\
\text { resistance }\end{array}$ \\
\hline M1 & $2 \cdot 7 \times 10^{3}$ & $5.0 \times 10^{0}$ & ND & - \\
\hline M2 & $4 \cdot 1 \times 10^{3}$ & $1 \cdot 1 \times 10^{3}$ & $1 \cdot 0 \times 10^{1}$ & - \\
\hline M3 & $9.0 \times 10^{2}$ & ND & ND & $\longrightarrow$ \\
\hline M4 & $5.0 \times 10^{4}$ & $5.0 \times 10^{0}$ & ND & - \\
\hline M5 & ND & ND & ND & $5.0 \times 10^{0}$ \\
\hline M6 & $1.4 \times 10^{2}$ & - & ND & $\ldots$ \\
\hline M7 & $6.5 \times 10^{2}$ & $3 \cdot 5 \times 10^{1}$ & ND & $3.5 \times 10^{1}$ \\
\hline M8 & $2.6 \times 10^{3}$ & ND & ND & - \\
\hline M9 & $1.05 \times 10^{2}$ & - & ND & - \\
\hline M10 & $1.1 \times 10^{2}$ & - & ND & - \\
\hline M11 & ND & ND & - & 一 \\
\hline M12 & ND & ND & ND & - \\
\hline M13 & $2.4 \times 10^{2}$ & $8.9 \times 10^{2}$ & $5.0 \times 10^{0}$ & ND \\
\hline M14 & $2.3 \times 10^{4}$ & $2.4 \times 10^{4}$ & ND & ND \\
\hline M15 & ND & ND & ND & ND \\
\hline M16 & ND & ND & ND & 一 \\
\hline M17 & ND & ND & ND & - \\
\hline M18 & ND & ND & ND & 一 \\
\hline M19 & $5.0 \times 10^{3}$ & ND & ND & - \\
\hline
\end{tabular}

ND, No transfer detected; - , organism sensitive to antibiotic.

presence of restriction endonucleases in the wild strains was obtained. Such enzymes seem to be typical of phage group II rather than other groups (Stobberingh \& Winkler, 1976). However, the presence of endonucleases indifferent to the effect of heat has not been excluded; such enzymes might be phage-associated.

\section{Examination for defective prophage carriage in cultures M2, M14 and M17}

Since there is good evidence for epidemic spread of prophages in staphylococci (see Introduction) and that some previously isolated methicillin-resistant organisms harbour such phages (Lacey, 1972), and since cultures M9 and M11 each contain an inducible prophage (see above), it is possible that cultures M2, M14 and M17 contain remnants of previously acquired temperate prophages.

Such defective prophages might transfer determinants from these cultures to a recipient in mixed culture experiments, since the transfer vehicle in mixed culture mating is probably a defective prophage (Lacey, 1975). Accordingly, transfer of antibiotic resistance from each of the cultures M1 to M19 to 6936 was attempted. Tetracycline resistance was transferred to the recipient from 12 out of the 19 donors, $\mathrm{Cd}^{2+}$ resistance and penicillinase production from 6 out of 16, erythromycin resistance from 2 out of 18, and neomycin resistance from 2 out of 5 donors. No transfer at all was detected from 6 strains (Table 5). Resistance to streptomycin (from 19), to methicillin (from 19) and to gentamicin (from 5) was nontransferable. Not only was the highest incidence that of transfer of tetracycline resistance amongst the potential donors, but the frequency obtained was also higher than the other resistances. These findings are characteristic of transferable resistance in Staph. aureus (Lacey, 1975) and are consistent with the proposal that the transfer vector is a defective bacteriophage.

Further evidence for this was obtained by showing that environmental conditions favourable for transfer from M2 and M4 were also optimal for the transfer of resistance from strain 609, a known lysogenic donor (Lacey, 1971). Thus, the presence of $\mathrm{Ca}^{2+}$ or $\mathrm{Mg}^{2+}$ promoted transfer and citrate abolished it; high cell density was associated with a 
Table 6. Effects of ions on the transfer of tetracycline resistance from strains M2, M14 and 609 (control) to recipient culture 6936

Results are expressed as the number of resistant recipients $\mathrm{ml}^{-1}$ after incubation of the mixed culture for $24 \mathrm{~h}$.

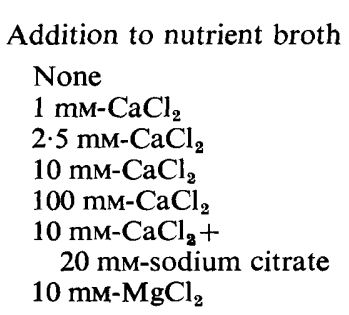

\begin{tabular}{ccc}
\multicolumn{3}{c}{ Donor strain } \\
$\mathrm{M} 2$ & $\mathrm{M} 14$ & 609 \\
0 & 0 & 0 \\
$2 \cdot 1 \times 10^{2}$ & $6 \cdot 8 \times 10^{2}$ & $7 \cdot 4 \times 10^{2}$ \\
$1 \cdot 1 \times 10^{3}$ & $2.8 \times 10^{3}$ & $2.9 \times 10^{3}$ \\
$2 \cdot 7 \times 10^{2}$ & $5.0 \times 10^{4}$ & $3.0 \times 10^{4}$ \\
$7 \cdot 5 \times 10^{2}$ & $6 \cdot 2 \times 10^{2}$ & $1.2 \times 10^{3}$ \\
0 & 0 & 0 \\
$5 \cdot 5 \times 10^{2}$ & $1.5 \times 10^{2}$ & $4.8 \times 10^{3}$
\end{tabular}

Table 7. Association of cell density with the frequency of transfer of tetracycline resistance from strains M2, M14 and 609 (control) to recipient culture 6936

Mixed cultures in 3,10 or $25 \mathrm{ml}$ nutrient broth containing $10 \mathrm{~mm}-\mathrm{CaCl}_{2}$ in $25 \mathrm{ml}$ Universal bottles were incubated with aeration for $24 \mathrm{~h}$. The frequency of transfer of tetracycline resistance is expressed as the number of resistant recipients per inoculated donor cell. Final cell densities are indicated in parentheses.

$\begin{array}{cccc}\begin{array}{c}\text { Culture } \\ \text { volume } \\ (\mathrm{m} 1)\end{array} & \mathrm{M}_{\mathrm{M} 2} & \text { Donor strain } & \\ 3 & 4.0 \times 10^{-6} & 8.0 \times 10^{-5} & 7.1 \times 10^{-5} \\ & \left(5.4 \times 10^{9}\right) & \left(3.3 \times 10^{9}\right) & \left(2.5 \times 10^{9}\right) \\ 10 & 2.1 \times 10^{-7} & 4.5 \times 10^{-5} & 1.9 \times 10^{-5} \\ & \left(1.0 \times 10^{9}\right) & \left(5.5 \times 10^{8}\right) & \left(1.5 \times 10^{9}\right) \\ 25 & 1.3 \times 10^{-7} & 2.0 \times 10^{-6} & 3.4 \times 10^{-7} \\ & \left(3.0 \times 10^{8}\right) & \left(1.8 \times 10^{8}\right) & \left(1.6 \times 10^{8}\right)\end{array}$

high frequency of transfer (Tables 6 and 7). (It is not possible to ascertain whether it is the high cell density, oxygenation or other factors that are responsible for high transfer frequencies.)

Although cultures M2, M14 and M17 were not visibly inducible with ultraviolet light, this treatment could cause the release of non-lytic prophages if they were present. To test for this, cultures of M2, M14 and M17 that had been exposed to ultraviolet light for optimal induction (as shown by the lysis of strain 609) were filtered, and the filtrates were checked for sterility and then tested for their ability to transduce tetracycline resistance to strain 6936 in conventional transduction experiments. Tetracycline resistance was transduced $\left(3 \cdot 3 \times 10^{3}\right.$ per $\mathrm{ml}$ filtrate) from the filtrate of culture M14, a finding consistent with the presence of defective phage particles in that culture. Transduction was not successful with cultures M2 or M17.

Filtrates of the methicillin-resistant cultures other than M2, M14 and M17 were examined for the presence of plaque-forming activity on each of the propagating strains and on cultures 1030, 609 and 6936. Eight of the 16 cultures yielded no plaques on any of the indicator strains from overnight cultures and also from cultures treated with either mitomycin $\mathrm{C}$ or ultraviolet light. It is possible that the failure to detect lysis is due to the selection of inappropriate indicator cultures. However, filtrates from all the 11 methicillin-resistant cultures examined previously (Lacey \& Grinsted, 1973) produced lysis on at least one of these indicator strains. It is likely, therefore, that cultures M2, M14 and M17 contain defective prophages; it is also possible that the widening in typing pattern following nitrosoguanidine treatment is due to the elimination of such elements. 
In a recent survey, Rosendal et al. (1977) described methicillin resistance in staphylococci in phage groups other than in group III, and including group I. The findings here suggest a close relationship between phage groups I and III, and it is possible that phage group III methicillin-resistant (and perhaps also sensitive) staphylococci have evolved from phage group I. In favour of this suggestion is the natural history of the hospital staphylococcus over the last 25 years where epidemics of the group I complex have been generally replaced by group III strains. The evolutionary sequence from phage group I to III may have occurred through a series of lysogenic events, with subsequent loss of the capacity of the temperate phages to cause lysis. Two such phages in Staph. aureus have recently been characterized fully (Duval-Iflah et al., 1977). Further work is required to fully characterize these proposed defective phages.

I thank Drs J. D. Barrie, S. W. B. Newsom and R. D. C. Sinclair for providing cultures, and the East Anglian Regional Health Authority for a research grant.

\section{REFERENCES}

AnNear, D. I. \& GrubB, W. B. (1976). Methicillinsensitive variants in ageing broth cultures of methicillin-resistant Staphylococcus aureus. Patho$\log y$ 8, 69-72.

Asheshov, E. H. (1975). The genetics of tetracycline resistance in Staphylococcus aureus. Journal of General Microbiology 88, 132-140.

Asheshov, E. H. \& Jevons, M. P. (1963). The effect of heat on the ability of a host strain to support the growth of a Staphylococcus phage. Journal of General Microbiology 31, 97-107.

Asheshov, E. H. \& Rippon, J. E. (1959). Changes in typing pattern of phage-type 80 staphylococci. Journal of General Microbiology 20, 634-643.

Asheshov, E. H. \& WinkleR, K. C. (1966). Staphylococcus aureus strains of the ' $52,52 \mathrm{~A}, 80,81$ ' complex. Nature, London 209, 638-639.

Duval-Iflah, Y., Heijenoort, J. van, Rousseau, M. \& Raibaud, P. (1977). Lysogenic conversion for multiple characters in a strain of Staphylococcus aureus. Journal of Bacteriology 130, 1281-1291.

Grinsted, J. \& LACEY, R. W. (1973). Ecological and genetic implications of pigmentation in Staphy. lococcus aureus. Journal of General Microbiology 75, 259-267.

Jevons, M. P. \& Parker, M. T. (1964). The evolution of new hospital strains of Staphylococcus aureus. Journal of Clinical Pathology 17, 243-250.

Jevons, M. P., John, M. \& Parker, M. T. (1966). Cultural characters of a newly recognised group of hospital staphylococci. Journal of Clinical Pathology 19, 305-312.

LACEY, R. W. (1971). Transfer of tetracyclineresistance between strains of Staphylococcus aureus in mixed cultures. Journal of General Microbiology 69, 229-237.

LACEY, R. W. (1972). Genetic control in methicillinresistant strains of Staphylococcus aureus. Journal of Medical Microbiology 5, 497-508.

LACEY, R. W. (1975). Antibiotic resistance plasmids of Staphylococcus aureus and their clinical importance. Bacteriological Reviews 39, 1-32.
LACEY, R. W. \& GRINSTED, J. (1973). Genetic analysis of methicillin-resistant strains of Staphylococcus aureus; evidence for their evolution from a single clone. Journal of Medical Microbiology 6, 511-526.

OEDING, P. (1974). Cellular antigens of staphylococci. Annals of New York Academy of Sciences 236, 15-21.

Parker, M. T., Asheshov, E. H., Hewitt, J. H., Nakhla, V. S. \& Brock, B. M. (1974). Endemic staphylococcal infections in hospitals. Annals of New York Academy of Sciences 236, 406-484.

Ralston, D. J. \& BAER, B. S. (1964). A new property of phage group II Staphylococcus aureus: host restriction of phage K14. Journal of General Microbiology 36, 1-16.

Rosendal, K. \& BüLow, P. (1971). A subdivision of Staphylococcus aureus strains belonging to the $82 \mathrm{~A}, 84,85,6557,592$ complex with special reference to antibiotic resistance. Acta pathologica et microbiologica scandinavica B79, 377-384.

Rosendal, K., Jessen, O., Bentzon, M. W. \& Bülow, P. (1977). Antibiotic policy and spread of Staphylococcus aureus strains in Danish hospitals, 1969-1974. Acta pathologica et microbiologica scandinavica B85, 143-152.

Rountree, P. M. (1959). Changes in phage-typing patterns of staphylococci following lysogenization. Journal of Gereral Microbiology 20, 620-633.

Rountree, P. M. \& Asheshov E. H. (1961). Further observations on changes in the phage-typing pattern of phage type $80 / 81$ staphylococci. Journal of General Microbiology 26, 111-122.

Stobberingh, E. E. \& Winkler, K. C. (1976). Restrictionless mutants of Staphylococcus aureus. In Stophylococci and Staphylococcal Diseases, pp. 313-324. Edited by J. Jeljaszewicz. Stuttgart: Gustav Fischer Verlag.

Willis, A. T., Smith, J. A. \& O’Connor, J. J. (1966). Properties of some epidemic strains of Staphylococcus aureus. Journal of Pathology and Bacteriology 92, 345-358. 